\title{
JUAN DE AMPUES
}

\author{
VREDELIEVENDE INDIANENJAGER
}

DOOR

\author{
C. $\mathrm{CH}$. Goslinga
}

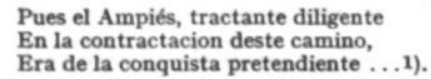

Pues el Ampiés, tractante diligente En la contractacion deste camino, Era de la conquista pretendiente...1).

Immers, Ampues, die ijverige koopman In het sluiten van contracten op deze wijze, In het sluiten van contracten op deze wijze,

In de door modernere onderzoekingen wel aangevulde en verbeterde, doch nog steeds onvervangbare Geschiedenis van Venezuela door BARALT en DiAz ${ }^{2}$ ), wier werk meer dan een eeuw geleden onder het tweede presidentschap van Generaal PÁEZ werd gepubliceerd, worden enkele beweringen geuit over een figuur die eveneens voor Curaçao van enig belang is geweest, namelijk JUAN MARTíneZ DE AMPUÉs ${ }^{3}$ ).

De tweede paladijn der Venezolaanse geschiedschrijving, GIL ForTOuL, hoewel veel moderner en onder invloed van het guzmancistische positivisme minder romantisch dan BARALT, onderschrijft niettemin diens beweringen vrijwel critiekloos, voor zover het tenminste AmpuÉs betreft. Latere Venezolaanse historici als Lecuna, Arcaya, Parra Pérez of Javier Yanes sluiten zich bij de eenmaal vastgelegde beoordeling aan of zwijgen er over. De Noordamerikanen die zich wat diepgaander met de ,conquista” hebben bezig gehouden, zoals BÉRNARD MOSES, steunen voornamelijk op BARALT.

Ernstiger is natuurlijk, dat de voor het middelbaar onderwijs bestemde schoolboeken, zowel in Venezuela als op de Nederlandse Antillen, de door BARALT en GIL ForToul gesuggereerde

1) Juan de Castellanos, Elegias, Parte II, Introd.

2) BARAlt \& Dfaz, Resumen de la Historia de Venezuela. RAMón DíAz verzorgde voornamelijk de bijlagen.

3) Ook wel geschreven AmpIÉs of AMpúes. 
misvatting omtrent AMPUÉs' karakter en bedoelingen getrouw copiëren. Zo komt een legende in de wereld die uiterst moeilijk zal zijn uit te roeien: die van de Indianenvriend AmpuÉs.

Baralt ziet in JuAn DE AmpuÉs, door hem genoemd ,sujeto de discreción y de buen entendimiento" ${ }^{1}$ ) de eerste Indianenvriend in de reeks van ,conquistadores”, ontdekkers en plunderaars, die de Tierra Firme van hun belangstelling blijk gaven. Hij zou dan de man zijn wiens nobele bedoelingen, in schone navolging van het grootse voorbeeld dat de Beschermer der Indianen, BARTolomÉ DE LAS CASAS, een tiental jaren te voren had gegeven, tot richtsnoer hadden moeten strekken voor andere veroveraars, wier zucht naar goud en slaven zulke hemeltergende toestanden schiep in het land van welks bewoonsters Castellanos zingt:

Que no se les manchaba vestidura

Que causase desdén a su belleza:

Por ser las ropas de su compostura

Aquellas que le dió naturaleza ${ }^{2}$ ).

BARALt ziet in AmpuÉs de man die voor een groot deel de bedoelingen van LAS CASAS wist te verwerkelijken, namelijk die van een vreedzame kolonisatie, hand in hand gaande met een daadwerkelijke bekering, de man wiens poging daartoe, ware zij niet afgebroken door het WELSERregiem, meer succes beloofde dan die van de idealistische en hartstochtelijke bisschop van Chiapa, LAS CASAS. In de bloemrijke bewoordingen die het Spaans eigen zijn, bewierookt de overigens ook vaak classisistisch aandoende Venezolaan dit streven dat hij AmpuÉs toeschrijft; verheerlijkt hij de opbloei van diens stichting Santa Ana de Coro, door AmpuÉs' zoon in opdracht van de vader als eerste steunpunt van diens gezag op het vasteland uitgekozen, niet ver van de kust, met een tweetal gunstige havens ${ }^{3}$ ). En deze bloei wordt dan vooral toegeschreven aan de uitstekende verhouding met de inboorlingen.

In felle termen wordt vervolgens KAREL V gelaakt, , monarca guerrero y ambicioso", die helemaal niet gesteld op dergelijke vreedzame penetratie, Europa doorging ,en alas de la victoria”, van veldslagen zijn bezigheden maakte en tenslotte, verarmd, een der schoonste streken van de Nieuwe Wereld prijsgaf aan de roofzucht van vreemdelingen. Dat deze - voor de Spanjaard vreemdelingen, niet voor KAREL V nogal op avontuurlijke wijze hebben huisgehouden in de hun toegewezen provincie Venezuela en Cabo de la Vela geven wij onmiddellijk toe, ondanks de beweringen van Duitse historici die hun landgenoten verdedigen. Dat de WeLSERS in hun gouddorst, veroveringszucht en slavenjacht

1) BARALT \& Díaz, I p. 169: Een verstandig en redelijk man.

2) Castellanos, Elegias, XI, canto V, p. 115 :

kleding bezoedelde hen niet

die hun schoonheid zou doen verachten,

want wat hun tooi uitmaakte

was wat hun de natuur had gegeven.

s) gesticht 26 juli, dag van S.Anna. Puerto de la Vela en Puerto San Bartolomé. Het zullen wel niet veel meer dan diepe baaien geweest zijn. 
het Spaanse voorbeeld overtroffen, moet worden ontkend. „Es war ein Abenteuer nach spanischem Vorbilde; begonnen ohne ernsthafte Aussichten auf kaufmännischen Nutzen und trotz des ebenfalls nach spanischem Muster betriebenen Ausbeutungssystems doch im wesentlichen nur mit kriegerischen Mitteln als echte „Conquista" durchgefürht.." 1 ).

GIL ForToul volgt het voetspoor van BARALT en schijft over AMPUÉs, dat hem in zijn omgang met de Indianen een zekere „dulcura”, zachtmoedigheid, kenmerkte en een grote mate van goed vertrouwen, die in fel contrast stonden met de brutaliteiten van mannen als OJEDA en OCAMPO ${ }^{2}$ ). AmpuÉs is dan de man die IsABELla's woorden om haar nieuwe onderdanen te behandelen ,,como los demas vasallos" naar geest en letter volgt, een voorloper op de practische toepassing van de bul „Sublimis Deus" van PAulus III, welke de redelijkheid van de Indiaan vaststelt en zijn ontvankelijkheid voor de christelijke dogmata aanvaardt ${ }^{3}$ ).

Uit hetgeen wij weten omtrent het optreden van JUAN DE AMPUÉs tegenover de Indianen moeten wij onmiddellijk concluderen - de feiten spreken een taal die niet geloochend kan worden - dat dit een groot verschil ten goede vertoont met de onmenselijkheid der beruchte ,indieros" of slavenjagers, wier schanddaden zelfs de uiteindelijke tussenkomst veroorzaakten van de Audiencia van Santo Domingo. Toch impliceert het constateren van dit feit geenszins, en ziedaar eigenlijk de bedoeling van dit artikel, dat AMPUÉs in zijn politiek tegenover de Indianen werd geïnspireerd door de pure belangeloosheid van menselijkheid en christelijke naastenliefde.

Ongetwijfeld staat AMpuÉs in de controverse tussen de optimisten van de "noble salvaje”, die de Indiaan een redelijke natuur toekennen en hen die zulks ontkennen, dichter bij de eerste categorie dan bij de laatste. En voorzeker is dit een trek die in zijn voordeel spreekt. Hij bevindt zich dan in het gezelschap van mannen als HeRnán Cortés en BARTOlomé DE LAS CASAS, die reeds in het begin van de xvie eeuw zagen, wat pas langzaam in de tweede helft van die eeuw begon door te dringen tot breder kring. Doch, ondanks het optreden van beide genoemde ,,conquistadores", de één van het $Z$ waard en de ander van het Woord, én van Columbus zelve, die de legende schiep van de ,edele wilde" "4) domineerde de eerste twee of drie decennia na de ontdekking van Amerika de pessimistische school van

1) Ehrenberg, Das Zeitalter der Fugger, I, p. 200.

2) GIL Fortoul, Historia Constitucional de Venezuela, I p. 21.

${ }^{3}$ ) Goslinga, in W. I. Gids 37, p. 147-161.

4) Hanke, La Lucha por la Justicia en la Conquista de América, p. 98. 
de „perro cochino”, „, de hondse vuilak", wier welsprekendste vertegenwoordiger die gezworen tegenstander van LAS CASAS was, Gonzalo Fernández de Oviedo, die als hij het over de Indiaan heeft, o.a. schrijft, dat deze alleen maar denkt aan,,comer, e beber, e folgar, e luxuriar, e idolatrar e exercer otras muchas suciedades bestiales" $\left.{ }^{1}\right)$. Nog erger maakt het de Dominicaan Tomas ORTIZ, die sommige Caribische stammen niet alleen van kannibalisme beschuldigt, doch ook van sodomie, terwijl een andere Dominicaan, Domingo DE Betanzos, beweert, dat de Indianen niet konden studeren en men in dit opzicht niets van hen mocht verlangen ${ }^{2}$ ).

Het is algemeen bekend, dat dit conflict van opvattingen over de redelijkheid van de Indiaan, waarbij de scheidingslijn dwars door de geestelijkheid heenloopt en de grote PAULUS III met zijn reeds genoemde bul van 1537 zich definitief plaatst aan de zijde van hen die CHRIsTus' woord: ,GGaat heen en onderwijst alle volken der aarde" ook op de min of meer barbaarse bewoner van Amerika willen toepassen, zijn culminatiepunt vond in het beroemde dispuut tussen LAS CASAS en JUAN GINÉS DE SELPúlvedA. De verbeten voorvechter van de Indiaan vond in de elegante humanist en gedegen kenner der Aristoteliaanse wijsbegeerte een hardnekkig tegenstander van zijn theorieën. Gelukkig waren er bekwame verdedigers van LAS CASAS' zaak bij de pauselijke stoel, tegenstanders van de „,bruta animalia” van SEPÚlveda en hierbij behoren zeker vermeld te worden de Dominicaan Bernandino de Minaya, die Paulus III opzocht om hem zijn standpunt bekend te maken, en diens ordegenoot Julian Garcés. Het belang van Paulus' bul voor de Nieuwe Wereld en de Indiaan is kortweg transcendentaal te noemen ${ }^{3}$ ).

JUAN DE AMPUÉs zal zich zeker niet ten volle bewust zijn geweest van de heftige strijd die de ,noblesse de soutane” boven zijn hoofd en dat van andere „conquistadores” uitvocht. De tijdgenoot ziet immers moeilijker wat zijn generatie beroert of wat uitsteekt boven de kleine oneffenheden der dagelijkse gebeurtenissen, dan de geschiedschrijver, die de opschriften opstelt voor de overwoekerde graven. Wanneer AMPUÉs in zijn houding tegenover de Indiaan blijken geeft van zekere menslievendheid,

1) HANke, p. 96: hun voornaamste bezigheid was eten, drinken, boeren, ontucht bedrijven, aan afoderij doen en allerlei bestialiteiten uitvoeren .....

2) HANKe, p. 100.

3) HANKe, p. 117. 
christelijkheid zo men wil, dan wil dat nog niet zeggen, dat hij een volgeling is van LAS CASAS en diens eindeloze peroraties over de "noble salvaje”, zoals ze tussen het geschiedkundig feitenmateriaal van de terecht beroemde Historia de Las Indias zijn ingeweven, tot de zijne maakt. Trouwens, LAS CASAS had zijn uitvoerig betoog toen nog niet geschreven. Veeleer moet men AMPUÉs' houding toeschrijven aan wat meer gezond verstand, dat het spreekwoord verstaat van de onwillige honden en dat zich laat leiden door een weloverwogen eigenbelang, dat geen christelijke naastenliefde kent als ze nadeel brengt en deze uitbuit als er voordelen van verwacht worden. Of hogere motieven ooit bij hem een rol hebben gespeeld, lijkt mij zeer twijfelachtig, ondanks de suggesties van BARALT en GIL ForToul. Figuur van ondiscussieerbaar en onvergelijkbaar kleiner formaat dan de grote CoRTÉs, die het Kruis bracht met het Zwaard, was AMPUÉs de grote Veroveraar van Nieuw Spanje in de practijk van zijn omgang met de Indiaan ongetwijfeld vooruit, al zijn dan van hem geen brieven bekend, zoals van CoRTÉs, waarin gepleit wordt bij het hof voor de redelijkheid der nieuwe vazallen ${ }^{1}$ ).

Het schijnt vrijwel zeker te zijn, dat het schandaal, dat de slavenjagers met hun plunder- en strooptochten op de Tierra Firme veroorzaakten en de daardoor veroorzaakte ontstellende ontvolking, de Audiencia van Santo Domingo tot een eindelijk ingrijpen noopten ${ }^{2}$ ). BARALT die in bloemrijke taal schrijft over het „escándalo producido por estos salteamientos" 3) steunt daarbij waarschijnlijk op het werk van AGUADO. Doch ook in de oude geschiedkundige werken over Santo Domingo wordt deze reden immer naar voren gebracht, wanneer de zending van JUAN DE AMPUÉs ter sprake komt. De klachten, ingebracht bij de koninklijke „,oidores" spreken van ,,les plus affreux brigandages” en een „,désordre criant" 4) en werden tenslotte zo herhaaldelijk geuit, dat de Audiencia niet langer afzijdig kon blijven. Tot zelfs in Spanje werd de echo van deze schanddaden dermate luidklinkend, dat het Hof een ambtenaar zond - Rodrigo dE FigueroA - die namens de Spaanse regering eens poolshoogte kwam nemen en moest onderzoeken, hoe het stond met de uitvoering der bepalingen welke door de Raad van Indië in 1511 en 1512 waren gemaakt om de Indianen te beschermen, d.w.z. de vredelievende en tot coöperatie met de Spanjaarden geneigd zijnde stammen, zoals veelal de Arowakken, tegen de vaak oorlogszuchtige en krijgshaftige

1) HANKE, p. 101

2) Hamelberg, 2e Jaarverslag Geschied-, Taal-, Land-en Volkenkundig Genootschap, p. 143; waarschijnlijk zal hierover wel het een en ander berusten in het archief van de Audiencia, Santo Domingo.

3) BARAlt \& Díz, I p. 168.

4) Xavier de Charlevoix, Histoire de l'Isle Espagnole ou de S. Domingue, I p. 449. 
Cariben. Doch ook hielden de wetten van Burgos in een protectie van de nieuwe vazallen tegen piraten en boekaniers.

Het optreden van Figueroa deed de Audiencia uit haar lethargische houding ontwaken. Het rapport dat deze ambtenaar der Centrale regering opstelde, ging in de richting van een zo groot mogelijke bescherming der autochthone, vredelievende bevolking tegen Spaanse en Indiaanse usurpatoren en uitbuiters. Contradictoir aan deze aanbeveling is daarbij de wonderlijke uitzondering, die Figueroa maakt: de Noordkust van Zuid-Amerika, i.c. Venezuela, benevens de daarvoor gelegen eilanden ${ }^{1}$ ). Met andere woorden: deze eilanden, waaronder Curaçao, Bonaire en Aruba, en de Tierra Firme werden prijsgegeven aan de ,,indieros", die meestal opereerden vanuit Cubagua, zodat dit eiland nog lange jaren een bloeiende slavenmarkt kon zijn, waar de levende koopwaar voor verder transport werd afgeleverd, o.a. naar Española. Hier was reeds in het begin van de $16 \mathrm{e}$ eeuw door de moordende arbeidsvoorwaarden een groot tekort ontstaan aan inheemse werkkrachten ${ }^{2}$ ).

Deze uitzondering doet wonderlijk aan, daar juist deze streken zo hevig werden geteisterd. De onvermoede werkelijkheid van de toestanden die er heersten, wordt treffend geillustreerd in de kroniekafbeeldingen van de Indiaan Guzmán Poma, die, ofschoon eigenlijk betrekking hebbende op Nieuw Spanje, toch ook voortreffelijk van toepassing zijn op het Caribisch gebied. Men ziet er de mishandelde Indiaan, gekneveld en geknield om medelijden smeken met de symbolische voorstellingen van zijn onderscheidene onderdrukkers om zich heen: poema, draak, kat, rat en jaguar, achtereenvolgens uitbeeldend: cacique, corregidor, soldaat, handelaar en geestelijke, tegenover wie hij machteloos is en aan wie hij weerloos is overgeleverd ${ }^{3}$ ).

Volgens een Real Cédula van 19 mei 1511 was AmpuÉs aangesteld tot factor van Española, andere besluiten regelden zijn salaris, „,80 mil maravedis al año" en een bepaald recht, de „almojarifazgo", een soort in- en uitvoerrecht ,,por los mantenimientos que condujese a la Isla Española. $\left.{ }^{4}\right)$. Tevens werd de Gouverneur en overige autoriteiten van Española opgedragen „para que puesten el auxilio que necesite al Factor JUAN DE AMPIÉs".

Reeds in Spanje had AmpuÉs zich onderscheiden als officier van het Spaanse leger, dat in heel Europa zulk een geduchte naam had ${ }^{5}$ ). Of hij toen reeds de opdracht heeft gekregen om de alle spuigaten uitlopende slavenjacht in het Caribisch gebied te beteugelen, is met de gegevens waarover wij beschikken,

1) HaEbler, Die überseeischen Unternehmungen der Welser, p. 136.

2 Diffie, Latin American Civilization, p. 192.

3) BRANDI, Keizer Karel V, p. 148.

4) Hamelberg, p. 143: voor de levensmiddelen die hij naar Española bracht.

5) Encyclopedia Universal Ilustrada Europeo-Americana, V p. 269. 
niet vast te stellen, maar lijkt ons niet waarschijnlijk. Immers, er mogen dan toen reeds klachten zijn binnengekomen bij de Audiencia, doch het tot in Spanje weerkaatsende heftige geluid van Montesinos en het vurige protest van LAS CASAS kwamen pas enige jaren later.

Nauwelijks was AMPUÉs op Española aangekomen, of hem werden als „Factor de la Española y Corregidor de la Ciudad de Santo Domingo" tweehonderd Indiaanse slaven in ,repartimiento"' ter beschikking gesteld ${ }^{1}$ ).

Aanvankelijk moet hij zich zeer verdienstelijk gemaakt hebben. Een koninklijk besluit van 1515 bedankt hem voor de vele diensten die hij heeft bewezen ${ }^{2}$ ). Doch enige jaren later rees er verdenking tegen zijn integriteit en kregen de licenciados LETRON en VADILLO opdracht een onderzoek in te stellen naar de ,abusos cometidos por el Factor JUAN DE AMPUÉs". In 1526 is deze kwestie nog steeds hangende, doch de situatie schijnt zich toch ten gunste van AMPUÉs aan het wijzigen te zijn, daar KAREL V met een koninklijk decreet de ,oidores" van Santo Domingo opdraagt ,que amparen a JUAN DE AMPIEs la posesion de las islas de Curazao, Curaba y Buynari" ${ }^{3}$ ). De adviezen uitgebracht door de paters Hieronomieten en FigueroA moeten dit besluit van KAREL hebben beïnvloed. In een ,,sobre-carta", een herhaald bevel, bevestigt KAREL deze opdracht en voegt hij er een aantal instructies aan toe betreffende het weer bevolken van deze eilanden.

JUAN DE AMPUÉS maakte dus deel uit van wat wij kunnen noemen de ,hoge ambtenarij” van Española. Als zodanig kreeg hij aanstonds de beschikking over 200 slaven, die voornamelijk afkomstig waren van de kleine Antillen voor de Venezolaanse kust. Hij behandelde deze slaven goed, in tegenstelling tot andere "encomenderos" of slaveneigenaars op het eiland en kwam er door herhaalde gesprekken met hen achter, dat zij ten onrechte in hun vernederende en afhankelijke toestand waren geraakt. Zij waren niet gevangen als ,esclavos de guerra”, met de wapens in de vuist zich verzettend tegen de Spanjaarden, doch geroofd door hun vijandige Indianenstammen, die hen naar de ,indieros" op Cubagura hadden doorverkocht. Zij behoorden niet

1) HAMELBerg, p. 143

2) Menkman, De Nederlanders in het Caraibisch Zeegebied, noemt hem: „,blijkbaar een verdienstelijk koloniaal ambtenaar”, p. 11.

3) Hamelberg: , dat zij de eilanden Curaçao, Curaba en Buynari onder bescherming stellen van Juan de Ampués", p. 14. 
tot de krijgshaftige Cariben, voor wie FigueroA, daar zij van kannibalisme werden beschuldigd, misschien zijn reeds genoemde uitzonderingsbepaling had gemaakt, doch tot de meer zachtmoedige Arowakken.

Als Factor en Corregidor kreeg AmpuÉs dus de opdracht tot vreedzame kolonisatie van de „Islas de los Gigantes”, i.e. Curaçao, Bonaire en Aruba. Zijn voorstellen daartoe waren zozeer een mengeling van vredelievendheid, menselijkheid en daarmede onlosmakelijk verweven eigenbelang, dat het bijna niet mogelijk lijkt, dat de Audiencia zijn sluwe en berekenende spel zou hebben doorzien en zich heeft gevleid met de suggestie van een pogen in de geest van LAS CASAS ${ }^{1}$ ).

In zijn studie over Aruba deelt Hartog omtrent AMpuÉs' bedoelingen het volgende mede: „Ten selven tijde deed JAN D'AmpuEs, koninglijke factoor in 't Eylandt Hispaniola, den Koning verhaal, dat in den Jaare 1513, de Catholijke Koningen berigt zijnde, dat om d'Indianen der onnuttelijke Eylanden t' onderwijzen, het noodig was, hen na Hispaniola te voeren .... en dat diegeenen die hem bequaamer scheenen dan die der andere Eylanden om Christenen te worden, hij dan verlof van den Admiraal Diego Columbus, om deese Eylanden te bevolken had versogt om hen tegen de Krijgslieden te beschermen en al het quaad dat men hen toevoegen kon af te wenden; en dat Columbus hem sijn verzoek bewilligt had onder seekere voorwaarden waar van hij den Koning de bevestinge versogt, die hij hem toestond; onder voorwaarde dat hij naauwkeuriglijk nakoomen sou wat aangaande de bekeeringe en 't goed onthaal der Indiaanen bevoolen was; en dat sijne Majesteit voor al verstond, dat se geene Slaaven wierden, nog men hen qualijk handelde; maar dat se als Vrije Lieden en als zijne Ondersaaten gehouden wierden gelijkerwijs men in Castlie gewoon was te oefenen" ${ }^{2}$ ).

Dit klinkt natuurlijk heel erg fraai doch, naar ook HaRToG opmerkt. toch wel heel doorzichtig.

Op de hoogte gekomen door zijn gesprekken met zijn Indiaanse slaven, dat de tegenoverliggende vastelandskust heel rijk was aan hout - vooral het zogenaamde Brazielhout, ook wel campêche- of stokvishout genoemd - trad hij met de Indianen van de Tierra Firme in contact, zonder daartoe enige machtiging van de Audiencia te hebben gekregen, doch zo al niet met haar officiële toestemming, toch wel met haar stilzwijgende instemming.

Dit verfhout vond AMPUÉs aanvankelijk in ruime mate op Curaçao en reeds spoedig wist hij van de Spaanse regering een

1) BARAlt \& DíAz, I p. 170.

2) Hartog, Aruba, p. 29. 
contract los te krijgen - met als compagnon een zekere JUAN FERNÁNDEZ DE CASTRO - gedateerd 27 november 1527, dat een monopolie toestond voor uitvoer en levering van genoemd hout naar alle Spaanse koloniën. Het behoeft geen betoog, dat dit feit de legende weerlegt als zouden uitsluitend de Hollanders Curaçao houtarm hebben gemaakt. Lang vóór de eerste Hollander zich in de Caribische wateren waagde, hakten Indianen in Spaans repartimiento hout voor AMPUÉs en zijn volgelingen, eerst op de eilanden, aan AmpuÉs' zorg toevertrouwd, later in Coro.

Wij zien evenwel dit contract niet als doel door AMPUÉs beoogd om én de eilanden én de vastelandskust te bezetten om hun houtrijkdom. Zijn bedoeling komt duidelijk uit in het citaat uit HARTOG's werk, al is ze daar met de saus van kerstening en onderwijzing overgoten. Hij wil vooral een vinger hebben in de profijtelijke pap der slavenjacht, doch het plompe middel van geweld bekoort hem niet. Wanneer hij zijn pogingen daartoe ziet mislukken door het optreden van het WELSER-regiem, poogt hij weliswaar zijn tegenstrevende houding te verdedigen door er op te wijzen, dat de WELSERS hem verhinderden hout te kappen en uit te voeren, doch ook in dit protest zien wij slechts een alfeidingsmanoeuvre in het motiveren van een inval die hoofdzakelijk het verwerven van slaven tot doel had ${ }^{1}$ ).

Uit welbegrepen eigenbelang trad AMPUÉs menslievend en verzoenend op tegen zijn Indiaanse slaven: zij moesten de beste propagandisten worden om zijn komst voor te bereiden. Hij begreep, dat én voor een lonende exploitatie van dit nog weinig geëxploreerde gebied én voor het zonder enig bloedvergieten van Spaanse zijde verwerven van slaven, de verhouding met de voornaamste en machtigste stammen aldaar van het allerhoogste belang was. Daarom ook stuurt hij zijn zoon vast vooruit om het terrein te verkennen, zijn voormalige slaven daar vrij te laten en een steunpunt te stichten. Duidelijk wijzen daarop enige passages uit de bekende reisbeschrijving van Nicolas FEDERMANN : ,das er ihme ein gutten willen unther den Naturales oder Indies machte, und also ahn sich ziehe" ${ }^{2}$ ). Doch tevens maakte deze beroemde ontdekkingsreiziger er melding van, dat AMPUÉs met die vrijgelatenen zijn ware bedoelingen verried, daar hij hen uitsluitend als lokvogels gebruikte om Indianen te vangen en Indianen tegen Indianen uit te spelen. Dat hij daarbij geheel

1) Haebler, p. 163.

2) Federmann \& Stade, Reisen in Süd Amerika, p. 13. 
binnen de door de wet gestelde grenzen bleef, is duidelijk. Het gebied, dat de kust uitmaakt van het tegenwoordige Venezuela en gedeeltelijk ook nog Colombia, westelijk van de Cabo de la Vela, was immers door FIgUEROA nadrukkelijk uitgezonderd van de bescherming die andere streken en volken van de Spaanse Kroon ontvingen.

Deze motieven speelden een rol bij de stichting van Santa Ana de Coro, zelfs een doorslaggevende rol: het moest de eerste slavenmarkt worden op het vasteland. Dat de stad voor dat doel gunstig is gelegen, kan niet worden ontkend. Maar ook uitsluitend en alleen voor dat doel, ondanks de beweringen van BARALT ${ }^{1}$ ). Want ook als men haar wil beschouwen als steunpunt van een geregeld bestuur en als uitgangspunt van de vele ontdekkingstochten van Ambrosius EHINGER (of ALFINGer), Hohermuth, Federmann en Von Hutten staat ze bijna uitsluitend in dienst van materiële doeleinden: slaven en goud. Als deze doeleinden hun zin gaan verliezen, is haar rol spoedig uitgespeeld. Reeds JUAN DE CARVAJAL verplaatst de stad - wij laten de motieven die hem bewogen nu maar in het midden - en alleen als bisschopszetel behoudt dit beroemde centrum van kolonisten en avonturiers nog ongeveer een eeuw lang enige schaduw van grootheid. In politiek opzicht is haar rol na 1545 uitgespeeld.

Of AMPUÉs geheel uit eigen beweging naar het continent is overgestoken, is niet duidelijk. De gunstige berichten over hem die zijn vrijgelatenen verspreidden, bereidden in ieder geval een goede ontvangst voor. Dat het daaraan niet ontbroken heeft, staat wel vast, al weten we dan niet precies van wie het initiatief is uitgegaan ${ }^{2}$ ). De eerste geschiedschrijvers over de ontmoeting van AmpuÉs met MANaure, het beroemde opperhoofd der Caiquetíos, een stam der Arowakken, laten zich hier niet over uit. AGUADO, die ongeveer een halve eeuw later deze ontmoeting te boek stelt, schrijft alleen, dat AMPUÉs op de hoogte was van de aanwezigheid van de machtige stam der Caiquetíos en hun wijd en zijd bekende cacique. Fray Simón schrijft het werk van AGUADO bij deze episode vrij klakkeloos over ${ }^{3}$ ).

Het doet er ook niet zoveel toe. Manaure's stam stond bloot aan de usurpaties der ,indieros" en nu komt er een Spanjaard die bescherming aanbiedt, officiële protectie van die verre, voor

1) Baralt \& Díaz, I p. 169.

2) dit wordt nog onduidelijker, daar AMPUÉs' zoon hem is voorgegaan.

3) Acosta Saignes, in Rev. Nac. de Cult. 75, p. 19 e.v. 
de Indiaan legendarische Spaanse koning, wiens souvereiniteit moet worden erkend in ruil voor de nieuwe veiligheid. Het is de vraag of MANAURE wel een scherp begrip had van wat MosES hier noemt ,feudal subjection ${ }^{1}$ ). Ongetwijfeld is juist, wat JAVIER YANES daarbij opmerkt, namelijk dat AMPUÉS een wederzijds vertrouwen wist te vestigen door zijn overeenkomst met MANAURE ${ }^{2}$ ). Doch ook deze Venezolaanse geschiedschrijver vergist zich in AMPUÉs' voornaamste bedoelingen. Eigenbelang en hebzucht waren zijn drijfveren, conciliant optreden en vazaliteit aan de Spaanse kroon de middelen. Immers, men zou verwachten, dat hij ingevolge zijn monopolistisch contract betreffende het kappen en uitvoeren van speciale houtsoorten, zich zou hebben omringd met houthakkers en vredelievende handelaars. Niets is minder waar. AMPUÉs steekt naar Coro over met een gevolg van 60 Spanjaarden, waarvan het merendeel zich reeds eerder had doen kennen als ervaren ,,indieros", die berucht waren door hun geweldplegingen tegenover de Indianen, voorts buitengewoon ervaren bij het vangen van inboorlingen en doorkneed in de techniek van de slavenhandel. Zeker had AmpuÉs deze mannen niet bestemd om hout voor hem te gaan hakken. En wanneer AMPUÉs het veld moet ruimen voor EHINGER aarzelen deze Spanjaarden dan ook niet om in Duitse dienst over te gaan.

De legende heeft zich van verscheidene Indiaanse opperhoofden meester gemaakt en hen met een roem overtogen, welke de optimisten van de „,noble salvaje” een enorme voorsprong heeft gegeven op de pessimisten van de „perro cochino". Guaicaipuro, Tamanaco en Tiuna krijgen hun bronzen of stenen ,effigia” in het „Land van Bolivar”. Hun geschiedenis is echter nog weinig doorvorst, zodat het moeilijk is waarheid en dromen te scheiden. Misschien is dit zelfs niet eens meer mogelijk.

De Caiquetíos, waarvan MANAURE het machtigste opperhoofd was, staan niet als zo vredelievend bekend als sommige Venezolaanse geschiedschrijvers willen doen geloven. BARALT noemt hun stam „mansa en extremo", ${ }^{3}$ ) doch het is wel zeker, dat MANaure heel vaak op het oorlogspad was tegen naburige stammen - er heerste tussen deze nimmer duurzame vrede - en de sluwe Caiquetío bedreef zeker een niet minder geraffineerde politiek dan AMPUÉs, toen hij deze zo gul en gastvrij ontving. Een groot gevolg van meer dan 100 onderhorige hoofden omringde hem, toen hij de Spaanse factor welkom heette op zijn gebied, met hem een tractaat sloot en hem voor een waarde van meer dan 10.000 pesos aan geschenken overhandigde ${ }^{4}$ ). Door dat geschenk en door dit bondgenoot-

1) Moses, The Spanish Dependencies in South America, I p. 61.

2) Javier Yánez, Compendio de la Historia de Venezuela, p. 21.

3) Baralt \& DiAz I p. 169; buitengewoon zachtmoedig.

4) Arellano Moreno, in Rev. Nac. de Cult. 68, p. 96. 
schap kocht hij zich de bescherming van de Spaanse Koning, een bescherming die deze, geïnspireerd door het rapport van FigUEROA, hem en zijn volk had ontzegd. Maar ongetwijfeld had ook JUAN DE AMPUÉs moeilijk een betere keus kunnen doen, zij het dat het toeval hier wat heeft geholpen. Al was dan de stam der Caiquetíos niet zo vredelievend als BARALT beweert, zeker was ze „dócil a los halagos y buenos tratamientos" 1 ). Welnu, vleierij en goede behandeling waren juist de middelen, waarmede AMPUÉs zijn doel zocht te verwezenlijken.

Zijn overeenkomst met MANAURE verzekerde hem van een regelmatige en gewillige leverancier van krijgsgevangenen, die in de vaak door Spanjaarden opgestookte veten tussen de inboorlingen onderling als ,,esclavos de guerra”, geheel volgens de letter van het koninklijk decreet, geboeid naar Cubagua werden vervoerd om van daaruit hun weg te vinden naar de verschillende Spaanse nederzettingen, die altijd arbeidskrachten te kort kwamen. AMpuÉs fungeerde in deze transacties als de ,indiero pacífico", de vredelievende slavenjager, die zonder risico en bloedvergieten de voordelen inde van zijn diplomatieke menslievendheid.

Een lelijke streep door de rekening van AMPUÉs was wel, dat hij al heel spoedig zijn aanspraken - vermeende dan - op de provincie Venezuela heeft moeten opgeven. Of hij inderdaad nog een inval heeft gedaan in het aan de WELSERS geconcesseerde gebied, waarbij hij kon rekenen op MANAURE's steun, staat niet vast.

Vermeldenswaard in verband met AMPUÉs' veronderstelde menslievendheid is nog wel, dat de beroemde lofzanger der „Conquistadores”, de „CAMOES” der Spanjaarden, JuAN DE CASTELLANOS, in zijn terecht geprezen Elegias de Varones Ilustres niets weet van de vreedzame pogingen tot toenadering met de Indianen, doch wel AMPUÉs' bentgenoten karakterizeert als handige slavenjagers ${ }^{2}$ ).

Ook LAS CASAS gewaagt in zijn dikwijls wel zeer wijdlopige Historia de las Indias niet van de vreedzame kolonisatiepoging, welke AMPUÉs voorgaf te ondernemen en die, zo zij werkelijk oprecht gemeend was, zo zeer parallel liep met de pogingen die de grote Beschermer der Indianen ongeveer tien jaren te voren met zulke teleurstellende resultaten ondernomen had. Voor vreedzame kerstening gepaard met christelijke kolonisatie was én de tijd nog niet rijp én AMPUÉs niet de aangewezen man, al beweert Haebler, dat hij Manaure liet dopen en al hadden

1) gevoelig voor vleierij en goede behandeling.

2) Castellanos, II, introducción, p. 185. 
Hieronomieten paters op Curaçao te zijnen gunste bij het Hof geadviseerd.

Evenmin lijkt het mij in het voordeel van AMPUÉs' onderneming te zijn, dat het kolonisatieplan van HEINRICH EHINGER en Hieronymus SaIler ten dele is gebaseerd op het feit, dat het de Duitsers een uitgebreid jachtgebied - op slaven en goud in handen speelde. Het lijkt ons ongerijmd, dat de Consejo de Indias, die natuurlijk op de hoogte was van AMPUÉs' vestiging op Coro, ook al had hij daartoe langs officiële weg geen toestemming verzocht, een ernstige poging tot vreedzame kolonisatie zou verijdelen, indien hij er niet van overtuigd was geweest, dat AMPUÉs misschien wel in de middelen mocht verschillen, doch dat zijn bedoelingen in wezen geen andere waren dan die der brutale ,,indieros". Waarschijnlijk heeft het optreden van AMPUÉS de aandacht van de WELSERS juist gericht op een streek, waar zij meenden met de handel in Indiaanse slaven goede zaken te kunnen doen, zoals ook AMPUÉs zich dat had gedacht.

Dat zij daarbij niet hebben kunnen rekenen op de medewerking van Manaure, is ongetwijfeld een punt in het voordeel van AMPUÉs' optreden, wiens alle geweld vermijdend intrigeren op handige wijze de ene Indianenstam tegen de andere wist uit te spelen en zonder Spaans wapengeweld slaven wist te bemachtigen. De WeLSERS legden met hetzelfde doel voor ogen hun toeleg te weinig diplomatiek bloot, vertrouwden MANAURE misschien ook niet om zijn contract met AMPUÉs en de Indiaan trok zich met zijn stam in de bergen terug. De bescherming die AMPUÉs had gegeven, ontbrak vanzelfsprekend bij de WELSERS.

Het bleef AMPUÉs natuurlijk niet onbekend, wat zich aan het Spaanse Hof afspeelde, terwijl hij van Curaçao uit een blijvend gezag trachtte te vestigen in de Tierra Firme en de nieuwe stad Santa Ana de Coro daarvan het bewijs moest zijn. Zo alarmerend werden de geruchten, dat hij te midden van de onverkwikkelijke ruchtbaarheid, die zijn echtscheidingsproces met DoÑa FLORENCIA meebracht, onverwijld oversteekt naar Coro om zijn zoon aldaar te bezoeken ${ }^{1}$ ). Met een schrijven van 7 september 1528 richt hij zich dan tot de Audiencia van Santo Domingo en verzoekt haar, met verwijzing naar de tot dan toe bereikte resultaten, om de kolonisering van de provincie niet over te laten aan Duitsers, doch ze hem op te dragen ${ }^{2}$ ). Hij beroept zich in dit

1) López de Sagrado, Gobernantes de Maracaibo, p. 3.

2) Haebler, p. 142.

West-Indische Gids XXXVII 
schrijven op het feit, dat hij overeenkomsten had gesloten met de Indianen, dat hij zulks op vreedzame wijze had bereikt, dat hij het vertrouwen in de Spanjaarden had hersteld en dat bovendien de gehele onderneming althans voor een belangrijk deel door hem was bekostigd, terwijl men in Santo Domingo niet alleen meer dan eens duidelijke instemming had betoond met zijn optreden, doch er bovendien op had gezinspeeld, dat zijn aanspraken zouden worden erkend. Over zijn ware bedoelingen schrijft hij vanzelfsprekend niet.

De Spaanse regering stelde zich daarentegen op het juridisch ongetwijfeld juiste standpunt, dat AMPUÉs slechts rechten kon doen gelden op de drie kusteilanden en deze werden dan ook in de overeenkomst met de Duitsers nadrukkelijk uitgezonderd. Wel informeerde de Raad van Indië bij de Audiencia of Juan DE AMPUÉs een officiële opdracht van haar had ontvangen om naar het vasteland over te steken - hoewel de Raad naar alle waarschijnlijkheid op de hoogte was van de juiste toedracht - en toen de Audiencia, ondanks de welwillendheid waarmede zij AMPUÉs' daden had beschouwd en de instemming - zij het dan niet toestemming - die zij duidelijk en vaak genoeg had laten blijken, dit niet kon bevestigen, zette de Raad van Indië zijn besprekingen met het Duitse Handelshuis ${ }^{1}$ ) voort, wat tenslotte resulteerde in een contract, waarbij de provincie Venezuela en Cabo de la Vela (wij laten hier in het midden, welk territorium daarmede precies bedoeld werd) aan de Duitsers werd overgedragen.

AMPUÉs had zich ondertussen laten verleiden tot een nog al onberaden stap. Daar hij meende te kunnen blijven vertrouwen op de welwillendheid van de Audiencia, verliet hij Coro en ging hij terug naar Curaçao, niet echter zoals hij bij de Audiencia voorgaf, om aldaar inspecterende werkzaamheden te verrichten, doch om een aantal soldaten om zich heen te verzamelen en daarmede weer naar Coro terug te keren en de Duitsers, wanneer deze mochten komen, gewapende tegenstand te bieden. Deze poging, die misschien een kleine kans van slagen zou gehad hèbben bij het voortbestaan van de onlusten in het nabijgelegen Santa Marta - daar zij Gouverneur GARCía DE LERMA zouden genoodzaakt hebben een groot deel van het expeditiekorps dat

1) hoewel ik herhaaldelijk over de WELSERS spreek, is dat in dit stadium nog niet juist; het moet eigenlijk zijn het huis EHINGER en SAILER; later nemen de WELSERS de verplichtingen over. 
in Española klaar stond om zich naar de Tierra Firme te begeven in zijn provincie aan te wenden - faalde, omdat deze omstandigheden zich weldra wijzigden. Ook de Audiencia heeft haar welwillendheid ten opzichte van AMPUÉs niet zo ver laten gaan. dat zij hem in deze dwaasheid wenste te steunen. Zij maakte hem duidelijk, dat zij overtuigd was van de vastbeslotenheid der Spaanse regering om het contract met EHINGER en SAILER te doen erkennen.

Wat nu verder gebeurd is, is niet geheel duidelijk, OviEdo y BAÑos beweert, dat AMPUÉs zich bij de voor hem wel bijzonder teleurstellende gang van zaken geeft neergelegd en op correcte wijze Coro heeft overgedragen aan AMbrosius Ehinger, toen die aldaar op 27 februari 1529 landde ${ }^{1}$ ). JUAN PÉREz DE TOLOSA schrijft over deze overdracht op gelijke gunstige wijs $\left.{ }^{2}\right)$. BARALT laat er zich niet over uit, evenmin als GIL ForToul en, voorzover wij dat konden nagaan, andere Venezolaanse historici. Bernard Moses, die steunt op het werk van Humbert, beweert slechts dat EHINGER instructies kreeg ,,not to interfere in any way with AMPUÉs' administration of the islands left in his charge". en motiveert dat met het volgende: "lest he (AMPUÉs) should be placed in a position of disadvantage as a consequence of his hostility to Governor EHINGER ${ }^{3}$ )".

Alleen de Duitsers, die hoewel zij moeilijk op het WELSER-regiem de schone formule van "Gott und Gewinn" konden toepassen, daar alleen „Gewinn" het doel was der occupatie en exploratie, hebben deze overdracht nauwkeuriger bestudeerd. Dit geschiedde vanzelfsprekend niet alleen, omdat ze in de „WELSER-Züge" de eerste kolonisatiepogingen zien van de Duitsers in Amerika, maar ook, en zeker niet het minst, om de beschuldigingen door de Venezolanen tegen hun bewind geuit, te weerleggen. Deze immers zijn niet mis. Baralt spreekt van een ontvolking die zo groot was aan het einde van de Welser-periode, ,que por doquiera se elevó contra el gobierno de aquellos extranjeros un grito general de indignación" "4) en zijn sentiment proeft men duidelijk in het verachtelijke ,,aquellos extranjeros”. GIL ForToul is koeler kroniekschrijver, doch wijst er niettemin op, dat de Welsers nimmer de ,clausulas de su capitulación" met KAREL V hebben vervuld en zich bijna nooit bekommerden om wetten noch geboden ${ }^{5}$ ).

Konrad Haebler, wiens uitvoerige studie over het Welser-

1) HAEBler, p. 142.

2) Oviedo y Baños, Historia de la Conquista .... de Venezuela, II p. 369.

3) Moses, p. 61

4) BARAlt \& Díaz, I p. 193; dat zich overal tegen het bewind van die vreemdelingen een algemene kreet van verontwaardiging verhief.

5) Gil Fortoul, I p. 23. 
regiem weliswaar meer dan een halve eeuw oud is, doch nog geenszins verouderd, beweert, dat uit het proces dat JUAN DE AMPUÉs de WeLSERS heeft aangedaan, duidelijk blijkt, dat hij gewapende tegenstand heeft beproefd. Hij moest echter voor de overmacht wijken, immers EHINGER had 700 man voetvolk en 80 ruiters bij zich ${ }^{1}$ ). Zelfs heeft AMBrosius EHINGER AMPUÉs gevangen genomen. Beiden wendden zich daarop tot de Spaanse regering met een aanklacht tegen elkander. AMPUÉs zwijgt in de zijne wijselijk over zijn (mogelijke) gewapende interventie of interventiepoging in Coro, eveneens over zijn (mogelijk) verzet tegen EHINGER, doch beschuldigt de Duitsers ervan, dat zij hem verhinderden om verfhout te kappen en uit te voeren. Met deze aanklacht had hij succes, daar de Spaanse regering $25 \mathrm{fe}-$ bruari 1530 aan AMbrosius EHINGER opdracht gaf AMpUÉs niets in de weg te leggen voorzover dit de uitvoering betrof van zijn contract betreffende verfhout.

De Welsers kwamen natuurlijk met een tegenklacht. Zij beschuldigden AMPUÉs ervan zich te blijven bemoeien met de interne aangelegenheden van de provincie ${ }^{2}$ ). De Raad van Indië verwees deze klacht naar de Audiencia van Santo Domingo, met het dringend verzoek deze taak ten spoedigste te onderzoeken en af te handelen. Dit bracht de Audiencia in een moeilijk parket. Zij was niot bopaald onpartijdig goweost in de gehele gang van zaken, integendeel. Zij had AMPUÉs in zijn Venezolaans avontuur aangemoedigd en zijn onderneming min of meer gedekt door haar gezag. Vanzelfsprekend zat zij er nu een beetje mee in, dat haar in deze aangelegenheid een beslissing werd opgedragen. Het behoeft dan ook niet te verwonderen, dat dit proces is doodgebloed, zonder dat er een eindoordeel werd uitgesproken. Wel gaf de Audiencia AmpuÉs de gelegenheid nogmaals een klacht in te dienen tegen de WeLsERS, omdat deze hem kolonisten en slaven hadden afhandig gemaakt, terwijl hij deze zo hard nodig had bij de stichting van zijn nederzettingen. Waarschijnlijk worden met de kolonisten bedoeld de ,indieros" die naar de Welsers overliepen, toen Ampués terug moest gaan naar Curaçao.

De getuigenverklaringen waren in het algemeen niet erg gunstig voor AMPUÉs, zodat hij zijn klacht liet vallen en zich terug trok naar de hem toegewezen eilanden. Daarmede verdwijnt hij naar het tweede plan, waaruit zijn Venezolaans experiment,

1) Humbert, Los Alemanes en Venezuela, p. 14.

2) HAEBler, Hfd. VIII. 
dank zij zijn op berekening steunende humaniteit, hem even voor het wereldvoetlicht had gebracht. Als factor van deze eilanden en later als koninklijk ambtenaar op Española moet hij zijn land nog vele goede diensten hebben bewezen.

Een oordeel over deze figuur moet, met het vrij schaarse materiaal dat ons ter beschikking stond, uit de aard der zaak voorzichtig geformuleerd worden. Doch de vaagheid van aanduidingen die zijn gestalte met een waas van menselijkheid en naastenliefde omgaven, verdicht zich toch langzamerhand tot een scherper contour en er begint zich een profiel af te tekenen dat niet in zijn voordeel is. Met zekerheid menen wij te mogen betwijfelen - en wij hebben getracht dit aan te tonen - dat hij niet de goedwillende en zachtmoedige Indianenvriend is geweest, die tot nu toe gesuggereerd werd. Zijn goedwillendheid en zachtmoedigheid waren de veel gevaarlijker wapens van zijn winstbejag dan de ruwe plundertochten en grove mensenroof zijner tijdgenoten. Het lot, dat hem plaatste aan de rand der Nieuwe Wereld maakte ook van hem, wat het van zovele kleine en grote conquistadores maakte: een ,indiero", een Indianenjager. Hij paste echter een andere tactiek toe en trachtte, door het uitspelen van de ene Indianenstam tegen de andere, de in deze geprovoceerde oorlogjes gemaakte gevangenen contractueel af te kopen, wat hem ook gelukt is. Maar hebzucht en eigenbelang verduisteren daarbij het schoone beeld, dat van hem bestond.

Dat hij daarbij ook het middel der kerstening gebruikte, of liever misbruikte, is wel niet geheel zeker, doch schijnt op zijn minst toch wel heel waarschijnlijk. Ook dit wekke geen verwondering. In de bewogen tijd, waarin het hem gegeven was te leven maakte ook de Kerk zich niet dadelijk druk over dergelijke vrijheden, mits het grote doel maar gediend werd. Dat velen, ook geestelijken, niet onmiddellijk een juist inzicht hadden in het verderfelijke van een christianisering à tout prix, behoeft evenmin verwondering te wekken. Niet ieder was de geniale verziendheid beschoren van een LAS CASAS. Het wekke voor deze grote voorvechter der Indianen des te meer bewondering.

In zijn wel vaak zeer breedvoerige Historia de las Indias vermeldt de Beschermer der Indianen een aardig voorval van een inboorling die, toen hem door Spanjaarden werd gevraagd, of hij Christen was, ten antwoord gaf: „Si señor, yo ya soy poquito cristiano, porque ya saber yo un poquito mentir, otro 
día saber yo mucho mentir, y seré yo mucho cristiano" ${ }^{1}$ ). Dit is een voorbeeld van kerstening die op de huichelachtige grondslag is geschied van zogenaamde vredelievendheid en menselijkheid. Het slechte voorbeeld dat daardoor werd gegeven en waaraan naar onze mening JUAN DE AMPUÉs heeft medegewerkt, heeft de uitbreiding van het christelijk geloof meer geschaad dan de ruwe plundertochten der ongebreidelde ,,indieros". En het politiek geknoei, dat zijn optreden vergezelde, heeft meer bedorven dan de prediking der ,,conquistadores" met de punt van het zwaard.

JUAN DE AMPUÉs vredelievende slavenjager. Het is voorwaar géén eretitel.

\section{LITERATUUR}

Acosta Saignes, M., Aguado y Simón. Revista Nacional de Cultura, No. 75, 1949.

Aguado, Fr. Pedro de, Historia de Venezuela, (publicatie van de Real Academia de Historia met voorwoord en aant. van J. BÉcKER) $2 \mathrm{Dl}$ Madrid, 1918.

Arellano Moreno, A., La Economía pre-hispánica de Venezuela. Revista Nacional de Cultura, No. 68, 1948.

Baralt, R. M. \& DfAz, R., Resumen de la Historia de Venezuela, (Herdruk van de Academia Nacional de Historia de Venezuela) 2 Dl. Brussel, 1939.

Brandi, K., Keizer Karel V, (vertaling van N. B. TEnhaeff) Amsterdam, z.j. 2e dr.

CAsas, B. DE LAS, Historia de las Indias, (ed. Aguilar) Madrid, 3 Dl. z.j.

Castellanos, J. DE, Elegias de Varones Ilustres de Indias, (Deel 4 van de Biblioteca de Autores Españoles) Madrid, 1944.

Diffie, B. W., Latin American Civilization, Harrisburg, 1947.

Ehrenberg, R., Das Zeitalter der Fugger, 2 Dl. Jena, 1896.

Federmann, N. \& Stade, H., Reisen in Süd Amerika, 1529-1555, (uitgegeven in herdruk door KARL KLÜPPEL) Stuttgart, 1859.

Gil Fortoul, J., Historia Constitucional de Venezuela, 3 Dl. Caracas, $1942,3 \mathrm{e} d r$.

Goslinga, C. Сн., Kerk, Kroon en Cariben, West-Indische Gids 37, 1956, p. $147-161$.

HAEBleR, K., Die überseeischen Unternehmungen der Welser, Leipzig, 1903.

Hamelberg, J. H. J., Gegevens betr. Juan de Ampués. 2e Jaarverslag van het Geschied-, Taal-, Land-en Volkenkundig Genootschap, Amsterdam, 1898.

Hanke, L., La Lucha por la Justicia en la Conquista de América, (vertaling van Ramón Iglesia) Buenos Aires, 1949.

1) LAs CASAs, Historia de las Indias, II p. 310: Ja meneer, ik ben al een beetje Christen, omdat ik al een beetje kan liegen; spoedig zal ik goed kunnen liegen en dan zal ik een goede Christen zijn. 
Hartog, J., Aruba, Aruba, 1953.

Humbert, J., Los Alemanes en Venezuela, Burdeos, 1905.

Javier Yanes, Fr., Compendio de la Historia de Venezuela, Caracas, 1944.

López de Sagrado, J., Gobernantes de Maracaibo, Maracaibo, 1953.

Menkman, R., De Nederlanders in het Caraibisch Zeegebied, Amsterdam, 1942.

Moses, B., The Spanish Dependencies in South America, 2 Dl. New York, 1914.

Oviedo y Baños, J. DE, Historia de la Conquista y Población de la Provincia de Venezuela, 2 Dl. Madrid, 1885.

Xavier de Charlevoix, P. Pierre Fr., Histoire de l'Isle Espagnole ou de S. Domingue, 2 Dl. Parijs, 1730-31.

\section{RESUMEN}

\section{JUAN DE AMPUÉS, INDIERO PACÍFICO}

En los libros históricos de Baralt \& Díaz y Gil Fortoul la figura de Juan Martínez de Ampués, el fundador de Santa Ana de Coro, se destaca de las de otros indieros por su actuación pacífica y humana; a pesar de esto queremos desarrollar en nuestro artículo la tesis de que AMPUÉs fué inspirada también por motivos de codicia y egoísmo.

AMpUÉs se fué al continente con unos sesenta soldados - indieros en su mayoría - después de que un hijo suyo, adelantándose la expedición, había desembarcado en 1527 y fundado la ciudad de Santa Ana de Coro. Buscó un camino de coger esclavos indios de manera paćfica. Halló su oportunidad, cuando se asocí́ con Manaure, el cacique poderoso de los Caiquetíos. Manaure le suministró de esclavos como prisioneros de guerra en cambio de la protección de su persona y tribus por los españoles contra los pillajes de los indieros. Pues, según la relacíon de FigueroA, la Tierra Firme era excluída del amparo de la Corona y entregada a la merced, es decir la ferocidad y crueldad de los piratas y filibusteros.

Una prueba de que la actuación de Ampués no fué inspirada por motivos muy elevados se halla en el hecho de que sus compañeros tenían un renombre poco halagador como indiero y que, después de la entrega de la provincia de Venezuela a la Casa WELSER se alistaron sin vacilación alguna en las filas alemanas.

BARTolomé DE LAS CASAS nos relata en su Historia de las Indias de un indio que al preguntarle, si era cristiano, contest6́: „Si señor, yo ya soy poquito cristiano, porque ya saber yo un poquito mentir, otro día saber yo mucho mentir, y seré yo mucho cristiano". El mal ejemplo de Ampués en la conquista pacífica de las Indias, con mentiras y esclavitud, a veces bajo el signo de la Cruz, ha perjudicado la causa de la Iglesia más que todos los hechos crueles y guerreros de los conquistadores, que en su mayoría fueron hombres de honor, caballeros y a pesar de sus grandes defectos, cristianos.

iAmpUÉs, indiero pacífico; no es título de honor! 